\title{
Parametric Researchon Cost of Concrete Designed As Per 10262:2009
}

\author{
Prince Arulraj, Felix K Regi, Philo Mariya, Merin K Varghese, Abel Antony johns
}

\begin{abstract}
Concrete Mix design is the process of finding the right proportions of cement, fine aggregate, coarse aggregate ,water and admixtures to achieve strength and durability requirements. The procedure for designing concrete mixes for general types of construction are recommended in IS 10262:2009.This code is based on the experiments carried out at the national council for cement and building materials, New Delhi. The method is mainly based on the basic assumption that the compressive strength of concrete is governed generally by the water cement ratio. This study investigates the effect of other parameters also on the mix design and the cost of concrete.
\end{abstract}

Keywords - Mix Design, Strength, Durability.

\section{INTRODUCTION}

Concrete mix design focuses on selecting suitable ingredients of concrete and determining their relative proportions with the object of producing concrete having minimum strength \& durability and at the same time as economically as possible. The of mix designis used for specifying the mixture of ingredients required to meet the durability,target strength and workability.

An excel spread sheet was developed to calculate the quantity and cost of materials required so as to carry out the parametric study. The developed excel sheet can be used to design any mix between M20 and M45 as per IS10262:2009.Parametric study was carried out to determine the effect of specific gravity of coarse aggregate,specific gravity of fine aggregate,slump,Zone classification of fine aggregate,grade of cement and size of coarse aggregate on the cost of concrete.

\section{LITERATURE REVIEW}

[1]Mohammed ahmed saiful Islam et al.(2016)made a comparitive study of some popular concrete mix design methods namely fineness modulus method,ACI mix design method and DOE method from qualitative and cost effective point of view. A conclusion have been arrived that cost of concrete mix increases by increasing the concrete workability and maximum size of aggregate.Its cost is inversly proportional to water-cement ratio and directly proportional to the strength of concrete.

Revised Manuscript Received on April 12, 2019.

Prince Arulraj,Professor and Dean, Karunya Institute of Technology and Sciences.Coimbatore, Tamil Nadu, India.

Felix K Regi,Final year UG Students,Department of Civil Engineering@Karunya Institute of Technology and sciences.Coimbatore, Tamil Nadu, India.

Philo Mariya, Final year UG Students,Department of Civil Engineering@Karunya Institute of Technology and sciences.Coimbatore, Tamil Nadu, India.

Merin K Varghese, Final year UG Students,Department of Civil Engineering@Karunya Institute of Technology and sciences.Coimbatore, Tamil Nadu, India.

Abel Antony johns, Final year UG Students,Department of Civil Engineering@Karunya Institute of Technology and sciences.Coimbatore, Tamil Nadu, India.
[2]Prince Arulraj.G andVelusamy.K (2009) carried out a parametric study on concrete mix design as per IS: 102621982. They reported that there will be a saving of about 10 $\%$ in the cement content can be achieved if $20 \mathrm{~mm}$ aggregates are used instead of $10 \mathrm{~mm}$. If $40 \mathrm{~mm}$ aggregate is used instead of $20 \mathrm{~mm}$, the saving in the cement content will be around $11 \%$.

[3]Ashraf W.B and Noor M.A (2011) made a parametric study for assessing the effects of coarseness factor and workability factor on compressive strength of concrete. They reported that there might be relationship between the coarseness factor and the workability factor with compressive strength.

[4] Aminet al. (1999) made a parametric study on ACI method of concrete mix design. They reported that an inter particle void which is a function of a coarse aggregate grading is an important parameter in the mix design. They also reported that the ACI method has no adequate parameter to take this aspect into account and this could be the reason for the failure of mixes designed by ACI method to gain the required strength when coarse aggregate of higher voids are used.

[5]Prince Arulraj and Surthi made a comparison between the old and the new codes of BIS for concrete mix design. The reported that quantity of cement required slightly decreases when mixes are designed as per the new code for all grades of concrete. The requirement for fine aggregate was found to increase for all grades of concrete when mixes are designed as per the new code. The requirement of coarse aggregate was found to decrease for all the grades of concrete when mixes are designed by new code. For the same slump, the requirement of fine aggregate was found to be more and coarse aggregate was found to be less when the mixes are designed by the new code.

\section{MATERIAL}

The materials which are used for making the various mix are mentioned below;

Cement: Ordinary Portland cement of grade 43 and 53 confirming to IS 8112-1989 andIS12269-1987 were used for this investigation.

Aggregate: Broken granite stones of size 10,12,20,25mm were used as coarse aggregate. M-sand belonging to Zone 2 and Zone 3 were used as fine aggregate.

Water:The portable water was used for both mixing of concrete and curing of concrete. 


\section{CONCRETE MIX DESIGN}

\subsection{Factors influencingMix Design}

Compressive strength,workability,durability,max nominal size of aggregate, grading and type of aggregate, quality control and grade of cement are the factors influencing mix design.

\section{METHODOLOGY \& RESULTS}

The methodology consists of developing (1)Spread sheet to design concrete mixes as per IS10262 and carrying out the parametric analysis. Six parameters were considered for the parametric study. The parameters selected for the study and their values are given in Table 1.

Table 1: Parameters considered.

\begin{tabular}{|c|c|c|c|c|c|c|}
\hline Level & Zone & Slump & $\begin{array}{c}\text { Size of } \\
\text { CA }\end{array}$ & $\begin{array}{c}\text { Specific } \\
\text { gravity } \\
\text { of CA }\end{array}$ & $\begin{array}{c}\text { Specific } \\
\text { gravity } \\
\text { of FA }\end{array}$ & $\begin{array}{c}\text { Grade of } \\
\text { cement }\end{array}$ \\
\hline 1 & 1 & 50 & 10 & 2.2 & 2.2 & 33 \\
\hline 2 & 2 & 75 & 12 & 2.3 & 2.3 & 43 \\
\hline 3 & 3 & 100 & 20 & 2.4 & 2.4 & 53 \\
\hline 4 & 4 & 125 & 25 & 2.5 & 2.5 & - \\
\hline 5 & - & 150 & 40 & 2.6 & 2.6 & - \\
\hline 6 & - & - & - & 2.7 & 2.7 & - \\
\hline 7 & - & - & - & 2.8 & 2.8 & - \\
\hline
\end{tabular}

\section{Parametric Study}

\section{Effect ofSpecific Gravity of Fine Aggregate on Cost of} Concrete

In order to determine the effect of specific gravity of fine aggregate on the cost of concrete, the specific gravity of fine aggregate was varied between 2.2 and 2.8 with an increment of 0.1 .

M30 concrete was designed with the following data:

- Grade of cement:53

- Specific gravity of coarse aggregate:2.6

- Slump value:100

- Zone:3

- Specific gravity of fine aggregate:2.2 to 2.8 .

The material requirement and the cost of concrete are given in table2.

Table 2:Material requirement for concrete with Fine aggregate having different specific gravity values.

\begin{tabular}{|c|c|c|c|c|c|}
\hline $\begin{array}{l}\text { Specific } \\
\text { gravity } \\
\text { FA }\end{array}$ & $\begin{array}{l}\text { Water } \\
\text { content }\end{array}$ & Cement & F.A & C A & Cost \\
\hline 2.2 & 197.1 & 487.4 & 486.0 & 1110.6 & 5106.0 \\
\hline 2.3 & 197.1 & 487.4 & 508.1 & 1110.6 & 5132.5 \\
\hline 2.4 & 197.1 & 487.4 & 530.2 & 1110.6 & 5159.0 \\
\hline 2.5 & 197.1 & 487.4 & 552.3 & 1110.6 & 5185.5 \\
\hline 2.6 & 197.1 & 487.4 & 574.2 & 1110.6 & 5212.0 \\
\hline 2.7 & 197.1 & 487.4 & 596.5 & 1110.6 & 5238.5 \\
\hline 2.8 & 197.1 & 487.4 & 618.6 & 1110.6 & 5264.9 \\
\hline
\end{tabular}

The rate prevailing at Karunya nagar was adopted for the estimation of cost of concrete . Only material cost is included and it does not include labour cost.
From the Table 2, it can be seen that cement, water content and coarse aggregate are independent of specific gravity of fine aggregate.However the quantity of fine aggregate increases as the specific gravity of fine aggregate is increase. The cost of concrete also increases with respect to the specific gravity of fine aggregate.Variation of cost of concrete with respect to specific gravity of fine aggregate is shown in fig 1.

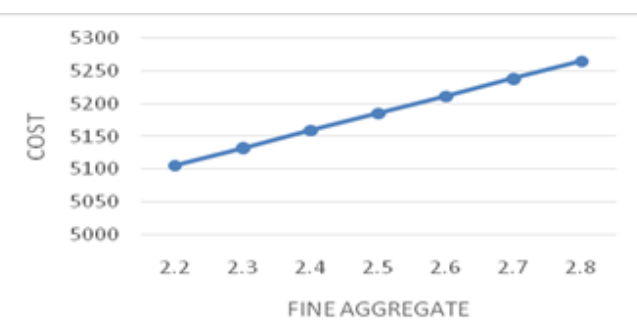

Fig1: Variation of cost of concrete with respect to specific gravity of fine aggregate.

From the figure, it can be seen that cost of concrete increases linearly with respect to the specific gravity of fine aggregate. The percentage increase in cost of concrete with fine aggregate having a specific gravity of 2.8 is $3 \%$ higher than that of the concrete with fine aggregate having a specific gravity of 2.2 .

\section{Effect of Specific Gravity of Coarse Aggregate on Cost of Concrete}

In order to determine the effect of specific gravity of coarse aggregate on the cost of concrete, the specific gravity of coarse aggregate was varied between 2.2 and 2.8 with an increment of 0.1 keeping other parameters constant.The material requirement and the cost of concrete are given in table 3 .

Table3: Material requirement in concrete with coarse aggregate having different specific gravity values.

\begin{tabular}{|c|c|c|c|c|c|}
\hline $\begin{array}{l}\text { Specific } \\
\text { gravity } \\
\text { C A }\end{array}$ & $\begin{array}{l}\text { Water } \\
\text { content }\end{array}$ & Cement & F.A & C.A & Cost \\
\hline 2.2 & 197.1 & 487.4 & 574.4 & 939.7 & 5068.4 \\
\hline 2.3 & 197.1 & 487.4 & 574.4 & 982.4 & 5094.9 \\
\hline 2.4 & 197.1 & 487.4 & 574.4 & 1025.1 & 5121.4 \\
\hline 2.5 & 197.1 & 487.4 & 574.4 & 1067.9 & 5147.9 \\
\hline 2.6 & 197.1 & 487.4 & 574.4 & 1110.0 & 5174.2 \\
\hline 2.7 & 197.1 & 487.4 & 574.4 & 1153.3 & 5200.9 \\
\hline 2.8 & 197.1 & 487.4 & 574.4 & 1196.0 & 5227.3 \\
\hline
\end{tabular}

From the Table 3, it can be seen that cement, water content and fine aggregate are independent of specific gravity of coarse aggregate. However as the specific gravity of coarse aggregate increases, the quantity of coarse aggregate required also increases. The costof concrete also increases with respect to specific gravity ofcoarse aggregate.Variation of cost of concrete with respect to specific gravity of coarse aggregate is shown in fig 2 .

Published By: Blue Eyes Intelligence Engineering 


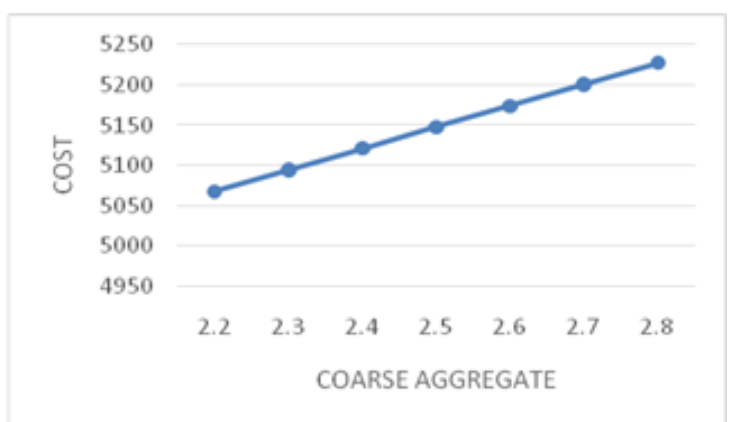

Fig2: Variation of cost of concrete with respect to specific gravity of coarse aggregate.

From the figure, it can be seen that cost of concrete increases linearly with respect to the specific gravity of coarse aggregate. The percentage increase in cost of concrete with coarse aggregate having a specific gravity of 2.8 is $3 \%$ higher than that of the concrete with coarse aggregate having a specific gravity of 2.2 .

\section{Effect of Slump on Cost of Concrete}

In order to determine the effect of slump on the cost of concrete, the slump value ranges from 50 to 150 was varied with an increment of 25.The material requirement and the cost of concrete are given in table 4.

Table 4:Material requirement for different slump values.

\begin{tabular}{|c|c|c|c|c|c|}
\hline $\begin{array}{c}\text { Slump } \\
\text { Value }\end{array}$ & Cement & Water & C A & F A & Cost \\
\hline 50 & 459.8 & 186.0 & 1144.7 & 637.6 & 5023.1 \\
\hline 75 & 473.6 & 191.5 & 1127.6 & 628.1 & 5117.5 \\
\hline 100 & 487.4 & 197.1 & 1110.6 & 618.6 & 5212.0 \\
\hline 125 & 501.2 & 202.7 & 1093.5 & 609.1 & 5306.4 \\
\hline 150 & 515.0 & 208.3 & 1076.4 & 599.6 & 5400.0 \\
\hline
\end{tabular}

From the Table 4, it can beseen that cement, water content and cost of concrete.However the quantity of coarse aggregate and fine aggregate decrease as slump increases. The cost increases as the slump value increases. Variation of cost of concrete with respect to slump value is shown in fig3.

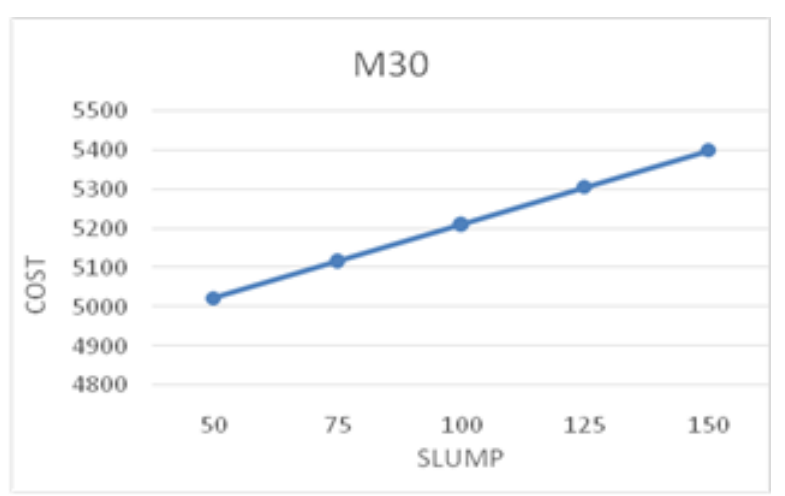

Fig3: Variation of cost of concrete with respect to slump value.

From the figure, it can be seen that cost of concrete increases linearly with respect to the slump value.The percentage increase in cost of concrete with slump having value of 150 is $7.5 \%$ higher than that of the concrete with slump value of 50 .

\section{Effect of Grade of Cement on Cost of Concrete}

In order to determine the effect of cement on the cost of concrete three grade of cement were tried. The material requirement and the cost of concrete are given in table5.

Table5:Material requirement for different grades of cement.

\begin{tabular}{|l|r|c|c|c|l|}
\hline $\begin{array}{l}\text { Grade } \\
\text { of } \\
\text { cement }\end{array}$ & Cement & $\begin{array}{l}\text { Water } \\
\text { content }\end{array}$ & C A & F A & cost \\
\hline 33 & 647.0 & 197 & 1054.7 & 536.8 & 6028.5 \\
\hline 43 & 592.9 & 197 & 1076.2 & 561.8 & 5651.5 \\
\hline 53 & 487.4 & 197 & 1110.6 & 618.6 & 5212.0 \\
\hline
\end{tabular}

From the Table 5, it can be seen the cost of concrete decreases as the grade of concrete increases.However the quantity ofcoarse aggregate and fine aggregate increase as the grade of cement increases.

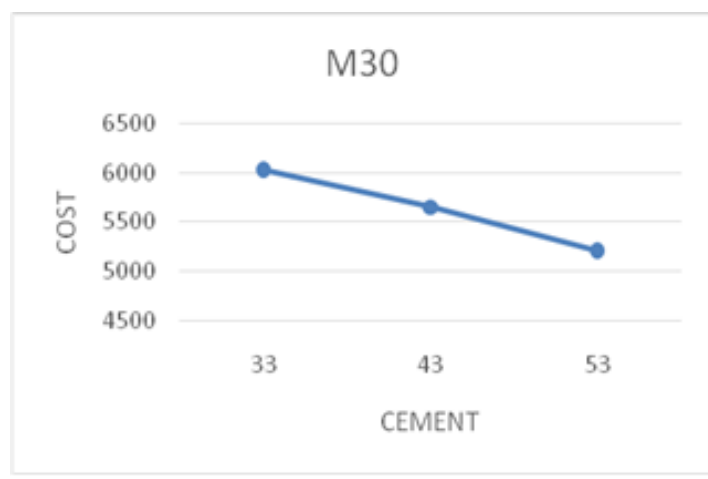

Fig4: Variation of cost of concrete with respect to grade of cement.

From the figure, it can be seen that cost of concrete decreases linearly with respect to the grade of cement. The percentage decrease in cost of concrete with cement having grade of 53 is $15 \%$ lower than that of the concrete with grade of cement of 33 .

\section{Effect ofZone on Cost of Concrete}

In order to determine the effect of zone on the cost of concrete, M30 mixes were designed with fine aggregate belonging to four zones. The material requirement and the cost of concrete are given in table 6 .

Table 6:Material requirement for different zones.

\begin{tabular}{|c|c|c|c|c|c|}
\hline Zone & Cement & Water & C A & F A & cost \\
\hline 1 & 487.4 & 197.1 & 1043.2 & 691.2 & 5232 \\
\hline 2 & 487.4 & 197.1 & 1076.9 & 654.9 & 5222 \\
\hline 3 & 487.4 & 197.1 & 1110.6 & 618.6 & 5212 \\
\hline 4 & 487.4 & 197.1 & 1144.3 & 582.32 & 5202 \\
\hline
\end{tabular}

From the Table 6 , it can be seen that quantity of coarse aggregate increases as the zone increases. The quantity of fine aggregate and cost of concretedecreases as the zone number increases. The quantity of fine aggregate decreases by $1 \%$ when then zone number changes from zone 1 to zone 4. 


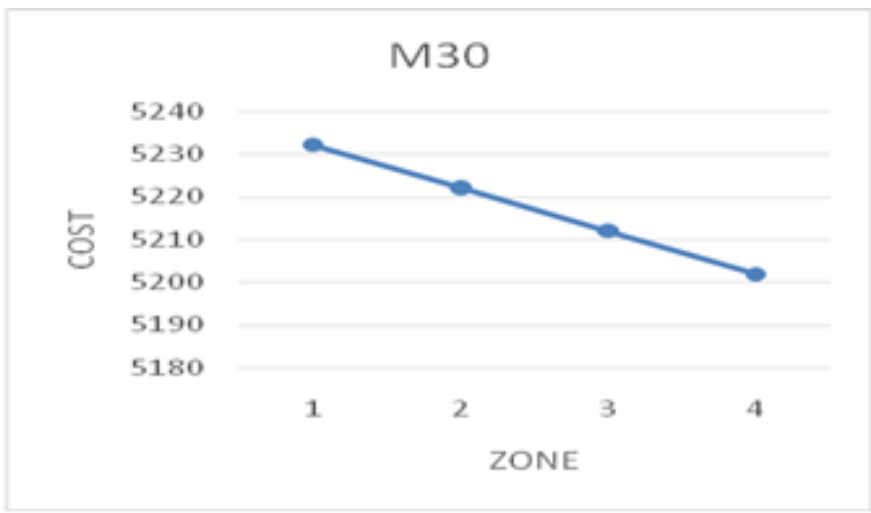

Fig5: Variation of cost of concrete with respect to Zone.

From the figure, it can be seen that cost of concrete decreases linearly with respect to the zone number.

\section{Effect of Size of aggregate on Cost of Concrete}

In order to determine the effect of zone on the cost of concrete, M30 mix was designed with coarse aggregates of five different sizes. The material requirement and the cost of concrete are given in table 7 .

Table 7: Material requirement for different size of aggregate.

\begin{tabular}{|c|r|r|r|r|r|}
\hline $\begin{array}{l}\text { Size of } \\
\text { aggregate }\end{array}$ & Cement & $\begin{array}{l}\text { Water } \\
\text { content }\end{array}$ & C A & F A & cost \\
\hline 10 & 545.09 & 220.4 & 787.0 & 850.58 & 5587 \\
\hline 12 & 533.56 & 215.8 & 848.9 & 807.17 & 5571 \\
\hline 20 & 487.43 & 197.1 & 1110.6 & 618.61 & 5212 \\
\hline 25 & 473.68 & 191.5 & 1161.8 & 591.24 & 5087 \\
\hline 40 & 432.40 & 174.9 & 1339.6 & 483.20 & 4764 \\
\hline
\end{tabular}

From the Table 7, it can be seen that as the size of coarse aggregate increases the quantity of cement, fine aggregate, water content andcost decrease. However,the requirement of coarse aggregate increases as the size of coarse aggregate increases. Variation of cost of concrete with respect to size of aggregate shown in fig 6 .

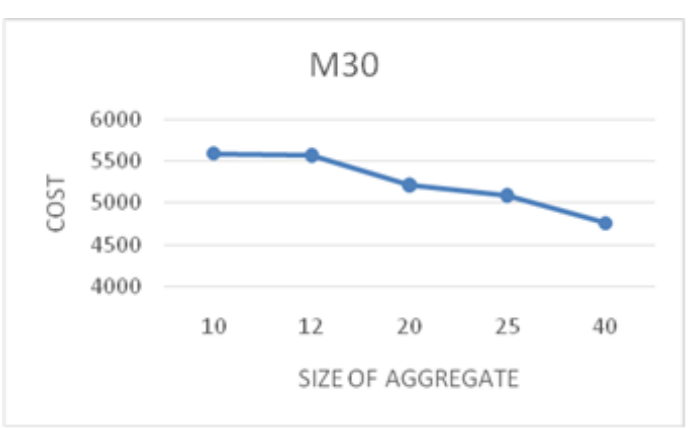

Fig6: Variation of cost of concrete with respect to size of aggregate.

From the figure, it can be seen that cost of concrete decreases with respect to the size of aggregate. The percentage decrease in cost of concrete having $40 \mathrm{~mm}$ aggregate is $17.2 \%$ is lower than that of concrete having aggregate of $10 \mathrm{~mm}$ size.

\section{CONCLUSIONS}

A parametric study on cost of concrete has been carried out. The various findings are:
- As the specific gravity of fine aggregate increases from 2.2 to 2.8 cost increases by $3 \%$.

- As the specific gravity of coarse aggregate increases from 2.2 to 2.8 cost increases by $3 \%$.

- As the slump value increases from 50 to $150 \mathrm{~mm}$, the cost increases by $7.5 \%$.

- As the grade of cement increases from 33 to 53, cost of concrete decreases by $15 \%$

- As the zone number varies from 1 to 4 , cost of concrete increases by $1 \%$.

- As the size of aggregate increases from $10 \mathrm{~mm}$ to $40 \mathrm{~mm}$, thecost of concrete decreases by $17.2 \%$.

\section{REFERENCE}

1. Mohd.Ahmed Saiful Islam.Sohaib Nazar.Roohul A.Khan."A Comparative Study of Popular Concrete Mix Design Methods from Qualitative and Cost Effective Point of View for Extream Environment". Arabian journal for science and engineering issue 4/2016.

2. Prince Arulraj.G and Velusamy. K, "Concrete Mix Design by IS Method - A Parametric Study", proceedings of the National conference on modern trends in civil Engineering, 20th March 2009, Page no $121-131$.

3. Ashraf .W. B andNoorM. A, "Experimental Comparative Study on theEffects of Cement Types of Concrete".Department of Civil Engineering, Bangladesh University of Engineering and Technology (BUET),31st Cement and Concrete Science Conference Paper Number XX Novel Developments and Innovation in Cemetitious MaterialsSeptember 2011 Imperial CollegeLondon, United Kingdom.

4. AminF. M. S.,Ahmad.S \&Wadud.Z, "Effect of ACIConcrete Mix Design Parameters on MixProportion And Strength", Bangladesh University of Engineering and Technology, Dhaka, Bangladesh, Civil and Environmental Engineering ConferenceNew Frontiers and Challenges, 8-12 November 1999, Bangkok Thailand .

5. Prince Arulraj . G and Sruthi Rajan'A Comparison Between the Old and New Indian Codes for Concrete Mix Design" The International Journal of Engineering and Sciences(IJES) vol 2,Issues 5,pg40-49,2013. 